\title{
Importance of Bats in Wildlife: Not Just Carriers of Pandemic SARS-CoV-2 and Other Viruses
}

\section{Katterine Bonilla-Aldana ${ }^{1,2}\left(\mathbb{D}\right.$, S. Daniela Jimenez-Diaz ${ }^{1}$, Shailesh Kumar Patel ${ }^{3}$,

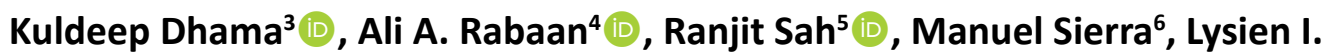 Zambrano $^{7}$ (D) Kovy Arteaga-Livias ${ }^{8,9}$ (iD) and Alfonso J. Rodriguez-Morales ${ }^{2,9,10 *}$ (D)}

\begin{abstract}
${ }^{1}$ Incubator in Zoonosis (SIZOO), Biodiversity and Ecosystem Conservation Research Group (BIOECOS), Fundacion Universitaria Autonoma de las Americas, Sede Pereira, Pereira, Risaralda, Colombia.

${ }^{2}$ Public Health and Infection Research Group and Incubator, Faculty of Health Sciences, Universidad Tecnologica de Pereira, Pereira, Risaralda, Colombia. ${ }^{3}$ Division of Pathology, ICAR-Indian Veterinary Research Institute, Izatnagar 243 122, Bareilly, Uttar Pradesh, India. ${ }^{4}$ Molecular Diagnostic Laboratory, Johns Hopkins Aramco Healthcare, Dhahran, Saudi Arabia. ${ }^{5}$ Department of Microbiology, Tribhuvan University Teaching Hospital, Institute of Medicine, Kathmandu, Nepal. ${ }^{6}$ Universidad Tecnologica Centroamericana, Tegucigalpa, Honduras. ${ }^{7}$ Departments of Physiological and Morphological Sciences, School of Medical, Sciences, Universidad Nacional Autonoma de Honduras (UNAH), Tegucigalpa, Honduras. ${ }^{8}$ Faculty of Medicine, Universidad Nacional Hermilio Valdizan, Huanuco, Peru. ${ }^{9}$ Masters in Clinical Epidemiology and Biostatistics, Universidad Cientifica del Sur, Lima, Peru. ${ }^{10} \mathrm{Grupo}$ de Investigacion Biomedicina, Faculty of Medicine, Fundacion Universitaria Autonoma de las Americas, Pereira, Risaralda, Colombia.
\end{abstract}

\section{Abstract}

Bats are the only flying mammals that carry multiple pathogens, such as the SARS-CoV-2. As a consequent of fear of the zoonotic origin of SARS-CoV-2, there is an adverse reaction in multiple countries against these animals. Bats contribute with arthropod control and pollination, among other positive roles of these animals.

Keywords: Bats, Coronaviruses, zoonotic diseases, wildlife, Pandemic, SARS-CoV-2

\begin{abstract}
*Correspondence: arodriguezm@utp.edu.co
(Received: April 15, 2020; accepted: April 23, 2020)

Citation: Bonilla-Aldana DK, Jimenez-Diaz SD, Patel SK, et al. Importance of Bats in Wildlife: Not Just Carriers of Pandemic SARSCoV-2 and Other Viruses. J Pure Appl Microbiol. 2020;14(suppl 1):709-712. doi: 10.22207/JPAM.14.SPL1.05

C The Author(s) 2020. Open Access. This article is distributed under the terms of the Creative Commons Attribution 4.0 International License which permits unrestricted use, sharing, distribution, and reproduction in any medium, provided you give appropriate credit to the original author(s) and the source, provide a link to the Creative Commons license, and indicate if changes were made.
\end{abstract}




\section{INTRODUCTION}

For decades it has been discussed the fragility of human life. That is directly related to the environmental changes and the human population interaction in their daily lives, generating interdependencies between the ecosystem and individuals in ecotones ${ }^{1}$. In this context, zoonotic diseases could be generated, emerging, or reemerging ${ }^{2,3}$, as has been the case of the Severe acute respiratory syndrome coronavirus 2 (SARS-CoV-2) ${ }^{4}$. Multiple pathogens and associated diseases may originate from animals and quickly be transmitted to humans, especially in rural areas, causing significant damage and burden ${ }^{5}$. Multiple sociocultural factors also may interplay.

\section{Coronaviruses}

Among the known zoonotic diseases, coronaviruses are included ${ }^{6}$. The viruses included in the Orthocoronavirinae subfamily, have appeared at different times in the 21st century 7. They originated in China and Saudi Arabia: the SARS-CoV, in late 2002, the Middle East Respiratory
Syndrome (MERS-CoV) in 2012, and the SARSCoV-2, causing the Coronavirus Disease 2019 (COVID-19), in 2020. These viruses are constantly evolving, and their primary carrier or natural host is the bat ${ }^{8}$.

In late 2019, the emergence of the SARS-COV-2 occurred in China ${ }^{9}$, but probably was circulating in wildlife for months or years. It is suspected to SARS-CoV-2 has originated from bats in the wildlife areas that provide of wild animals to the wet markets of Wuhan. Wild species found there included birds, snakes, groundhogs, shellfishes, among others. The commerce and the interaction with their fluids, such as blood and secretions, dead bodies, facilitated the spread of these viruses to humans, later globally distributed by international air travel, crossing borders and affecting the daily life of the communities, as well as also pressing genomic divergence in the interaction with humans in multiple continents ${ }^{10}$ (Fig. 1). That led to a pandemic, declared by the World Health Organization, that up to April

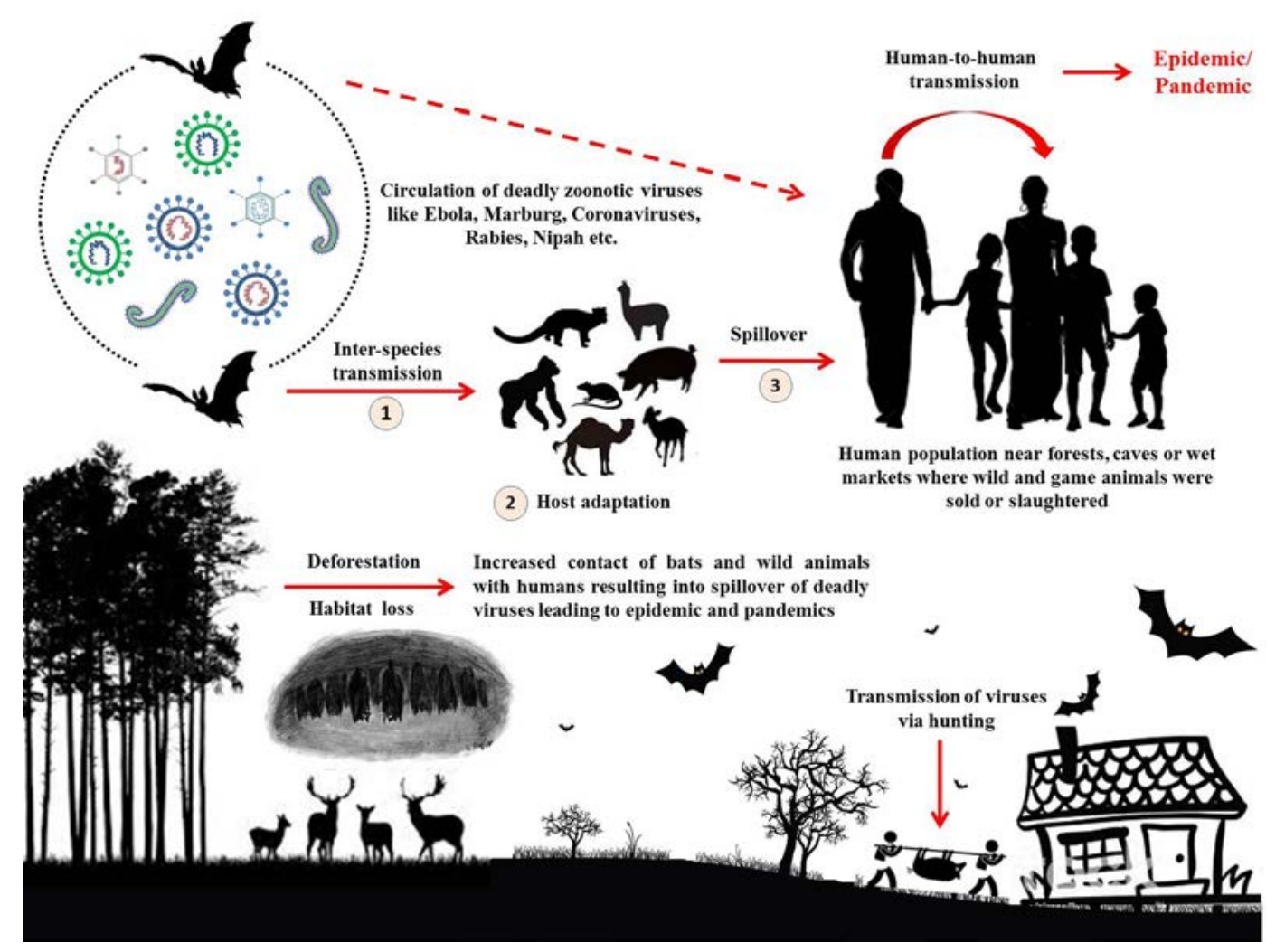

Fig. 1. Bat interactions, selected associated diseases, and the potential spillover to humans in the context of anthropogenic landscape changes and other related environmental and social factors 
28, 2020, have caused over 3.1 million cases worldwide, with multiple implications.

Because of the general perception that bats are responsible for the origin of this pandemic, human populations have generated prejudices about them, leaving aside the fact that man has invaded and destroyed spaces where they commonly coexist, concerning these viruses without affecting other species. As a result, animals have been forced to closer contact with humans, turning harmless their microbes into a public health threat ${ }^{4,9,10}$.

The invasion, of man in these spaces, is aimed at the commercialization of wild species used for the consumption and production of traditional medicine, mainly in China, but posing a risk for the spread of the SARS-CoV- $2^{11}$ (Figure 1). Moreover, news that label the bat as "guilty" of this outbreak, have generated aggressive human behavior against these mammals, for fear of being infected by the virus, due to the disinformation that exists in some territories. That has led to the people of some countries to burn them.

\section{Other Zoonotic Diseases from Bats}

Bats are the most widely distributed and abundant mammals after rodents and represent around one-fifth of the total mammalian population on the earth with more than 1,200 species. Bats play a critical role in a wide range of ecological events like pollination, insect control, seed dispersion, redistribution, and transfer of essential nutrients and are considered as an indicator of environmental health. Even though bats have been proven to be reservoirs of some human and animal viruses such as Rabies, Nipah, Ebola, Coronavirus, among others ${ }^{2,12}$, it is essential to recognize the central role they play in ecosystems ${ }^{13}$.

\section{Role of Bats in Nature}

The existence of bats is crucial for the well-being of human society, but they are continuously being threatened by habitat loss, climate change, persecution, and hunting. Bats are the only flying mammals that exist on earth and belong to the order Chiroptera which has been classified into two suborders (Megachiroptera and Microchiroptera) ${ }^{14}$. Megachiroptera feeds on plants, nectar, pollen, fruits, and seeds, allowing the diversification and maintenance of approximately 800 species of plants such as Agavaceae, Cactaceae, Leguminosae, because pollination can only be carried out by bats because their anatomical structures have the conditions to extract the nectar while the flower impregnates with pollen. Furthermore, they are responsible for regenerating trees and forests because they disperse two to eight times more seeds than birds ${ }^{15}$.

The suborder Microchiroptera, mainly feed on insects, small mammals, and blood. However, some species of bats such as bloodsuckers can generate diseases at livestock production. Most of these animals facilitate the control of arthropod vectors, associated to viral diseases such as Zika or damaging crops such as corn and cotton, since a bat can consume $150 \%$ of its body weight in insects every night, being the only mammals that can naturally eliminate large amounts of them in a single night ${ }^{15}$.

Bats differ from many other sylvatic reservoirs in their biologic properties like diverse and unique lifestyles, ability to fly, highly gregarious and crowded roosting behavior, extreme longevity, long lifespans, colossal population size, hibernation, seasonal migrations, and low fecundity rates. For a better understanding of the viral zoonoses and role of bats in the circulation of viruses with great zoonotic potential, epidemiologists and researchers must pay attention to the ecology and biology of bats. A thorough investigation of immune mechanisms of bats is necessary to reveal the reasons why bats are such efficient reservoir hosts.

\section{CONCLUSION}

Finally, taking into account a global scenario, it is vital to generate studies and education tools that contribute to reducing myths and strengthening the importance of bats in the ecosystems. Bats are significant for the environment impacting positively many economic and social aspects of human life, as mentioned, e.g. a natural biological control of arthropods, lowering the costs of production of crops and acquisition of related diseases.

\section{ACKNOWLEDGMENTS}

None. 


\section{CONFLICT OF INTEREST}

The listed author(s) declare no conflict of interest in any capacity, including competing or financial.

\section{AUTHORS' CONTRIBUTION}

All listed author(s) have made a substantial, direct and intellectual contribution to the work, and approved it for publication.

\section{FUNDING}

None.

\section{ETHICS STATEMENT}

This article does not contain any studies with human participants or animals performed by any of the authors.

\section{AVAILABILITY OF DATA \\ Not applicable.}

\section{REFERENCES}

1. Diaz S, Settele J, Brondizio ES, et al. Pervasive humandriven decline of life on Earth points to the need for transformative change. Science. 2019;366.

2. Bonilla-Aldana DK, Suarez JA, Franco-Paredes C, et al. Brazil burning! What is the potential impact of the Amazon wildfires on vector-borne and zoonotic emerging diseases? - A statement from an international experts meeting. Travel Med Infect Dis. 2019;31:101474. https://doi.org/10.1016/j. tmaid.2019.101474

3. Escalera-Antezana JP, Torrez-Fernandez R, MontalvanPlata D, et al. Orthohantavirus pulmonary syndrome in Santa Cruz and Tarija, Bolivia, 2018. Int J Infect Dis. 2020;90:145-50. https://doi.org/10.1016/j. ijid.2019.10.021

4. Bonilla-Aldana DK, Dhama K, Rodriguez-Morales AJ. Revisiting the One Health Approach in the Context of COVID-19: A Look into the Ecology of this Emerging Disease. Adv Anim Vet Sci. 2020;8:234-7. https://doi. org/10.17582/journal.aavs/2020/8.3.234.237
5. Rodriguez-Morales AJ, Bonilla-Aldana DK, IdarragaBedoya SE, et al. Epidemiology of zoonotic tick-borne diseases in Latin America: Are we just seeing the tip of the iceberg? F1000Res. 2018;7:1988. https://doi. org/10.12688/f1000research.17649.1

6. Ahmad T, Khan M, Haroon, et al. COVID-19: Zoonotic aspects. Travel Med Infect Dis. 2020:101607. https:// doi.org/10.1016/j.tmaid.2020.101607

7. de Wit E, van Doremalen N, Falzarano D, Munster VJ. SARS and MERS: recent insights into emerging coronaviruses. Nat Rev Microbiol. 2016;14:523-34. https://doi.org/10.1038/nrmicro.2016.81

8. Zhou P, Yang XL, Wang XG, et al. A pneumonia outbreak associated with a new coronavirus of probable bat origin. Nature. 2020;579:270-3. https://doi. org/10.1038/s41586-020-2012-7

9. Li Q, Guan X, Wu P, et al. Early Transmission Dynamics in Wuhan, China, of Novel Coronavirus-Infected Pneumonia. NEng/J Med. 2020;382:1199-207. https:// doi.org/10.1056/NEJMoa2001316

10. Rodriguez-Morales AJ, Balbin-Ramon GJ, Rabaan AA, et al. Genomic Epidemiology and its importance in the study of the COVID-19 pandemic. Infez Med. 2020;28:139-42.

11. Sun Z, Thilakavathy K, Kumar SS, He G, Liu SV. Potential Factors Influencing Repeated SARS Outbreaks in China. Int J Environ Res Public Health. 2020;17. https://doi. org/10.3390/ijerph17051633

12. Calderon A, Guzman C, Mattar S, Rodriguez V, Acosta A, Martinez C. Frugivorous bats in the Colombian Caribbean region are reservoirs of the rabies virus. Ann Clin Microbiol Antimicrob. 2019;18:11. https:// doi.org/10.1186/s12941-019-0308-y

13. Kunz TH, Braun de Torrez E, Bauer D, Lobova T, Fleming TH. Ecosystem services provided by bats. Ann N Y Acad Sci 2011;1223:1-38. https://doi.org/10.1111/j.17496632.2011.06004.x

14. Malik YS, Sircar $S$, Bhat $S$, et al. Emerging novel coronavirus (2019-nCoV)-current scenario, evolutionary perspective based on genome analysis and recent developments. Vet Q. 2020;40:68-76. https://doi.org/10.1080/01652176.2020.1727993

15. Fleming $T H$, Geiselman C, Kress WJ. The evolution of bat pollination: a phylogenetic perspective. Ann Bot. 2009;104:1017-43. https://doi.org/10.1093/aob/ mcp197 